Crime, Histoire \& Sociétés / Crime, History \& Societies

Vol. 21, $n^{\circ} 2$ | 2017

L'histoire de la criminalité et de la justice pénale : propositions de recherche pour le $21^{\mathrm{e}}$ siècle

\title{
Cultural Deviance, Political Crime, Public Media and Security: Perspectives on the Cultural History of Crime and Criminal Justice in Early Modern Europe
}

Karl Härter

OpenEdition

\section{Journals}

Electronic version

URL: http://journals.openedition.org/chs/1941

DOI: 10.4000/chs.1941

ISSN: 1663-4837

Publisher

Librairie Droz

Printed version

Date of publication: 31 December 2017

Number of pages: 261-269

ISSN: $1422-0857$

Electronic reference

Karl Härter, "Cultural Deviance, Political Crime, Public Media and Security: Perspectives on the Cultural History of Crime and Criminal Justice in Early Modern Europe", Crime, Histoire \& Sociétés / Crime, History \& Societies [Online], Vol. 21, n² | 2017, Online since 19 July 2020, connection on 13 January 2021. URL: http://journals.openedition.org/chs/1941 ; DOI: https://doi.org/10.4000/chs.1941 


\title{
Cultural Deviance, Political Crime, Public Media and Security:
}

\author{
Perspectives on the Cultural History of Crime and Criminal \\ Justice in Early Modern Europe
}

\author{
Karl Härter
}

$\mathrm{T}$ he historiography of crime and criminal justice in early modern Europe covers a wide array of topics and approaches, focusing on the social history of crime and conflict, violence and theft, the criminal justice system, penal law, punishments, procedure and infrajudicial conflict regulation. Although addressed in many studies and well-established historical issues, culture, religion, transnationality, politics and security still seem to be prospective fields for further research in the history of crime and criminal justice. Hence, the following essay attempts to exemplarily outline possible approaches to study the various interdependencies of culture, crime and criminal justice in early modern Europe by focusing on cultural diversity and deviance, political conflict and crime, judicial and popular media, and the concomitant security discourses.

This approach is able to draw on the recent "cultural turn" in the history of crime and criminal justice ${ }^{1}$ that has shifted the focus from the previous topics of "punishment, penal practice and culture" and "crime, criminals and literature" towards the cultural meaning and representation of crime and criminal justice in popular culture and print media, as well as the interdependencies between the various practices, communications and proceedings of criminal justice and the public sphere ${ }^{2}$. In the following I propose to further develop the new directions in the cultural history of criminal justice and to include - to a greater extent - cultural diversity, religious and political dissent, migration, transnationality and security as relevant research issues, which related disciplines have elaborated with regard to culture and criminal law/justice ${ }^{3}$. The first consequence of this would be to focus on the various functions and practises of the criminal justice system in dealing with specific forms of conflict, deviance and crime linked to diversity, transnationality and security as dimensions of cultural history - and to a certain extent intertwined with specific threats, narratives, discourses and (popular) media. In taking this as a basic starting point, two approaches seem to be especially promising.

Firstly, the relation of the early modern criminal justice system to cultural diversity and deviance. This includes the regulation of conflicts related to cultural differences (resulting from migration/transnationality, ethnicity, religion, politics) as well as the

For a recent general overview see the articles in Knepper and Johansen (2016, p.848-1043).

2 Devereaux and Griffiths (2004); Kalifa (2005); Lévy and Srebnick (2005); McMahon 2008; Wiltenburg (2012); Ward (2014).

3 Foblets et al. (2010); Melossi et al. (2011); Kymlicka et al. (2014); Mersmann and Kippenberg (2016).

Crime, Histoire \& Sociétés / Crime, History \& Societies 2017, vol. 21, n 2, pp. 261-269. 
criminalisation and prosecution of the respective crimes and groups, not to mention the cultural dimension of judicial practise and its agents and proceedings. Secondly, the interplay between the early modern criminal justice system and the public media that formed a "popular legal culture", which created and disseminated specific images, narratives and labels of threats, crime and justice linked with culture and security. This is based on the assumption that early modern criminal justice was also characterised by legal diversity, various forms of communication and infrajudicial practises.

If we conceptualise "culture" as collective "ways of life" - resulting from and manifesting in shared social practises, customs, habits, communications, attitudes and values - then early modern Europe was characterised by a growing cultural variety. Since the sixteenth century the ideal-typical uniform, hierarchical Christian society of orders has undergone a social, political, spatial and cultural differentiation that included the spread of various religions/"confessions" (denominations), increasing migration, and the growth of social and "ethnic" minorities. This resulted in an increase of cultural diversity, which we may define as "diverse cultures within

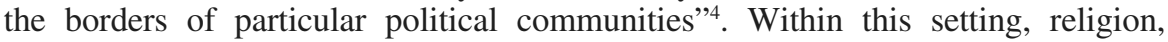
foreignness, migration, honour and, to some extent, gender constituted the main categories of cultural diversity, whereas categories such as age, sexual preference and ethnicity played a more limited role when it came to the perception of cultural differences. Although the political sphere did not constitute an element of cultural diversity per se, we can likewise observe a growing differentiation of political culture in early modern Europe that produced political diversity and dissent.

Overall, this growing cultural diversity challenged the Europe's various legal systems - and criminal justice in particular - since the resulting differences and conflicts, not to mention the respective groups, habits and practises, were perceived and labelled as deviant - in some cases even criminalised and prosecuted. This concerned, for example, migrating and marginal groups ("vagrants") as well as dissenting religious groups (criminalised as sects), or political dissenters (labelled as conspiracies). They were not only perceived as socially deviant but regarded as a threat to the state, security and order because of their deviant cultural attributes, habits and practises related to foreignness, language, migration, a mobile way of living, religious rites or political dissent - as well as the formation of (secretive) groups or associations that more or less "voluntarily" separated themselves from the "mainstream" society. Although not all of these cultural attributes constituted a crime per se, they were associated with typical elements or labels of criminal behaviour: the formation of secretive, dangerous and criminal groups or associations, such as robber gangs or heretical sects, illegal crossing of borders, thievery, robbery and violence as well as disobedience, sedition and upheaval.

Criminal justice history has studied some of these phenomena thoroughly, for instance, vagrants, bandits and robber gangs, with regard to their prosecution and punishment as well as concerning their respective images in popular media ${ }^{5}$. The recently bourgeoning field of religious deviance has also paid considerable attention to the cultural dimension of crime and criminal justice ${ }^{6}$. Furthermore, several studies dealing with the history of political crime - in particular regicide, assassination and

Foblets et al. (2010, p.xiii).

Rousseaux (2005); Garnot (2013); Gerstenmayer (2013).

6 Kästner and Schwerhoff (2013); Piltz and Schwerhoff (2015). 
revolt - have mapped the relations to popular media and the cross-border ties ${ }^{7}$. However, stressing the cultural dimension and the intertwined elements of cultural diversity and deviance, as well as combining this with the above-mentioned approaches, could very well prove profitable for future research.

A first step could be to extend the historical concept of crime as deviant behaviour criminalised in contemporary penal law and juridical discourses by adding and specifying intersected cultural elements, namely transnationality/migration, religious and political dissent and security. As mentioned above, I propose to focus on conflicts and crimes related to cultural diversity and dissent that the criminal justice systems in early modern Europe dealt with, in particular by labelling, criminalising and prosecuting culturally deviant behaviour and groups. Although this seems to be a somewhat vague concept of "cultural crime", several categories of cultural diversity can be linked with deviant/criminal behaviour and the concomitant labels and practices of criminal justice. This will be sketched out in the following three exemplary topics:

The first possible area of focus to study cultural diversity and crime could be migration and transnationality, which manifested in cross-border crimes and foreign, marginal groups labelled as mobile "criminal gangs". Recently, transnational history has focused its attention on cultural factors, and conversely, the transnational dimension is of great importance for the history of culture and criminal justice, in particular regarding such issues as migration, the exchange of goods, knowledge and media, or transnational crime ${ }^{8}$. Since the concept of "international crime" had not been established (or even invented) before the nineteenth century ${ }^{9}$, the transnational dimension of crime in early modern Europe was closely associated with groups and practises that were primarily perceived and labelled as foreign, mobile and culturally deviant. This concerned migrants, minorities and marginal groups such as vagrants, the Gypsies, the Jews (and other migrating mobile religious minorities), "infamous people", mercenaries and others with a nomadic lifestyle that crossed borders.

Based on the categories of foreignness, mobility/migration and, to some extent, ethnicity, they were not only perceived as culturally deviant but also labelled as threats to society, public order, and security and even linked with specific crimes. This manifested itself specifically in penal and administrative laws as well as in the concomitant juridical-political discourses observable in many early modern European countries at that time. They would enter countries unwelcomed, spread infectious diseases, seduce the residents and commit various crimes associated with their customs, habits and mobile way of life, namely idle, masterless and permanently wandering. Besides illegal migration and begging, they were associated with smuggling, the defrauding of customs (and other associated charges like convoy fees or supplementary taxes), cheating, thieving, robbing and murder. Although cultural differences constituted only one factor in the labelling of such groups, the transgression of spatial and cultural boundaries and the alleged "criminal culture" or "underworld" constituted pivotal elements of cultural deviance and "transnational crimes" that also influenced the practises of criminal justice.

The history of crime and criminal justice has indeed produced excellent studies

Salomé (2010); Härter and De Benedictis (2013); Härter (2014a); Härter (2016).

Mersmann and Kippenberg (2016).

$9 \quad$ Knepper (2010). 
on vagrants and robbers; however, instead of focusing on property crimes and violence, future research should consider placing greater emphasis on the cultural and transnational aspects: the context of migration and the prosecution of migrants and other culturally diverging, mobile groups as well as the spatial, transnational dimension and specific crimes of a cross-border nature. Furthermore, a more detailed examination of how early modern criminal justice systems dealt with the cultural and transnational dimensions of crime and the respective groups as well as how cultural attributes influenced the representation of crime and criminal justice in the public media and the respective crime and security discourses, for instance, with regard to the relation between general fears and crime panics, might prove quite fruitful ${ }^{10}$.

A second possible area of focus to study the cultural dimension of crime is religion, in particular crimes related to religious deviance, denominational or religious minorities (such as Jews or Muslims) and groups labelled as "criminal sects". Although traditional church and criminal law had criminalised dissident religious behaviour and belief as superstition, blasphemy or heresy, with the advent of the Protestant Reformation, and over the course of the early modern period, the concepts, narratives and practises of criminal justice underwent considerable change. Based on this, some researchers have suggested "religious deviance" as a prospective field of research ${ }^{11}$.

Specifically, this concerns cultural deviance and associated crimes of groups and minorities engaged in collective dissent with regard to religion, group configuration, mobility/migration and other diverging cultural practises. Labels, criminalisation and prosecution predominantly focused on the "sect" as a specific group that differed culturally but was also linked with criminal behaviour: they formed autonomous communities and secret groups within society that endangered order and security through disobedience, sedition and the seduction of subjects. Hence, from the authorities' perspective, religious deviance could lead to religious and political crimes such as revolt and overthrow. In this regard the concept of the "criminal sect" was related to that of "criminal conspiracy", for both fields of cultural deviance and crime were linked through similar narratives and labels associated with the dominating religious as well as political culture and security.

Research could not only further explore these interdependencies - in particular with regard to the practices of criminal justice - but also study in more detail how the criminal justice systems in early modern Europe dealt with religious deviance/crime and the respective minority groups, such as the Jews or the Gypsies, that differed in terms of culture, religion and ethnicity (or were perceived/labelled as such). The focus should not only include the repression and exclusion of religious minorities through criminal justice but should also be extended to the broader study of the meaning of religious and cultural factors for the prosecution, adjudication and punishment of such groups. Conversely, it would also be worth looking at the opportunities they had to access justice, to apply cultural agency and knowledge to their advantage (for instance, to defend themselves) or to use infrajudicial practices such as petitioning and pardon ${ }^{12}$.

A third possible area of focus for the further study of cultural diversity and criminal justice could be political dissent and crime, which formed an essential element of the

\footnotetext{
10 Rousseaux (2005); Lemmings and Walker (2009); Knepper (2010).

11 Kästner and Schwerhoff (2013); Piltz and Schwerhoff (2015).

12 Kallenberg (2015); Härter (2017).
} 
development of political culture in early modern Europe. Political dissent not only initiated political conflicts but generated culturally deviant behaviour that could be labelled as a political crime, ranging from seditious pamphlets and gatherings about upheaval and revolt to regicide, assassination and "criminal conspiracies". Its cultural dimension manifested in the performative and public nature of political conflict and dissent, the interconnection with religious dissent as well as in the responses of the legal systems involved and the media attention it received ${ }^{13}$. In this regard "political crime" constituted a specific label and legal mode for early modern political systems (and cultures) to respond to political conflict and dissent by means of criminal justice. The criminalisation of political dissent and the way criminal justice dealt with political crimes referred to basic elements (or labels) of cultural diversity and deviance: the dissenting group (often conceptualised as a criminal conspiracy operating in secrecy with divergent rituals and practises); the cross-border, transnational or foreign influences of other powers, groups and religions (e.g. the Jesuits or the "Papal conspiracy"); as well as the customs, opinions, ideologies and practises that differed from the dominant culture and that aimed at the seduction of subjects, the instigation of dissent and change and, therefore, constituted a fundamental threat to order and security.

Although research has produced several case studies dealing with political crimes and related incidents, only a few have combined the concepts and methods of criminal justice history with a cultural approach ${ }^{14}$. They focus on the responses of the concerned legal systems - notably the trial, the punishment, new legislation and preventative measures - as well as on the concurrent discourses and the representation of political crime in judicial and popular print. As cultural phenomena, political crime and the respective legal responses produced judicial media, such as the collections of state trials, and were covered by popular media such as illustrated broadsides and crime pamphlets. Besides the news and information, they conveyed - sometimes transnationally - culturally imprinted images and narratives, more typically including the "diabolical", "treacherous" assassin, the heroic victim, the political martyr, the religious nature of political crime or the foreign, transnational conspiracy ${ }^{15}$.

Consequently, the cultural meaning of political crimes (and the underlying conflicts) as well as the cultural dimension of criminal justice in dealing with such crimes and conflicts are prospective fields for further research. Specifically, it could focus on the interdependencies between political crime as a cultural phenomenon, the respective practices of criminal justice and the cultural representation (images, narratives) in popular media and the concomitant legal, political and security discourses. Moreover, a historical analysis of political crime and criminal justice could yield new insights into the political culture of early modern Europe and how it dealt with diversity, dissent and conflict.

As already noted, further research on the interdependencies of cultural diversity/ deviance, crime and criminal justice could elaborate methods and concepts recently developed in the history of crime and criminal justice. An initial approach could be to analyse the meaning and impact of cultural factors - including images and narratives - within the practice of criminal justice and related infrajudicial practises. A prerequisite for this, however, is grasping early modern criminal justice not as

\footnotetext{
13 Härter and de Graaf (2012); Härter and De Benedictis (2013).

14 Salomé (2012); Turrel (2012).

15 Härter (2014a); Härter (2014b); Härter (2016).
} 
a monolithic, enclosed state-based judiciary, but as a complex, diverse system of communicative interactions between various actors on different stages that also comprise judicial and infrajudicial practises and even extend to the broader cultural context, in particular through judicial and popular media and discourses.

As a result, different cultural actors, factors and images/narratives influenced communication, proceedings, adjudication and punishments. This generated ambiguous functions of criminal justice which merit further study: the criminalisation of behaviour that deviated also in cultural terms, the persecution of deviant cultural activities and practises as well as the social control, disciplining or exclusion of concerned groups. This raises the question whether criminal justice served to consolidate the cultural identity of a dominant society and produce cultural homogeneity. On the other hand, however, criminal justice could also regulate conflicts resulting from cultural diversity and deviance, and it could provide cultural opportunities or limited judicial autonomy for individual groups. If we conceptualise the protagonists of cultural diversity not as merely passive objects of criminal justice, a central question could be, how and to what extent did individual actors and groups use their "cultural agency" (customs, practises, knowledge, arguments and strategies) and infrajudicial opportunities (such as supplicating, petitioning, pardon, mediation, etc.) to negotiate conflicts, crimes or punishments and, in this respect, the boundaries of cultural diversity and deviance. The respective analyses of the varied and informative sources of early modern criminal justice could yield valuable insights if courts constituted an arena for cultural - in particular religious and political - conflicts, not to mention their management, regulation or settlement. Moreover, this approach could render further insights into the interplay between judicial and infrajudicial modes of criminal justice, since culturally diverging groups seem to be prone to regulate crime and conflict through extra- or infrajudicial institutions, proceedings and practises, especially if they were granted respective legal/judicial autonomies (as in the case of the Jews, for instance).

Given the fact that the early modern criminal justice system did not grant potential exemptions to cultural minorities, the application of modern concepts like "cultural evidence" or "cultural defence" could hardly be characterised as appropriate. But judicial diversity, infrajudicial practices and the specific culture of criminal procedure, as a performative and communicative interaction, which extended through judicial and popular media to the public sphere, enable the study of criminal justice as both a medium of a cultural discourse and a contest of cultural interpretation regarding deviant behaviour and crime. This can, for instance, be further studied with respect to the culturally grounded labels, narratives and images that the early modern criminal justice system applied, generated and disseminated through punishment, adjudication, prosecution and criminal law (and comparable public and administrative laws). Criminal justice constructed social and cultural differences, labelled (or criminalised) cultural practises and the transgression of cultural boundaries and, as a result, shaped culturally-based stereotypes and transferred the cultural dimension of crime into the public media and general security discourses.

Consequently, the well-established research on the representation of crime in public print could be extended to the more specific issues of cultural deviance and the interplay between criminal justice, public media and security discourses. The various forms of communication within the different judicial and infrajudicial settings of criminal justice influenced or even generated the development of related judicial, 
mainstream and popular print media, which as a whole formed a "popular legal culture" and was closely linked to the cultural dimension of criminal proceedings ${ }^{16}$. The English Collections of State-Trials, for instance, evolved out of the context of political crime, and Pitavals causes célèbres also focused on crimes related to cultural factors of crime and criminal justice. On the whole, judicial, pragmatic and popular print - ranging from judicial pamphlets and collections of decisions and cases to "search and wanted lists", "reports from the files" to last dying speeches, illustrated broadsheets, crime pamphlets, trial-collections, press and literature - created and disseminated not only images and narratives associated with cultural diversity and deviance, but also connected with the exemplary topics outlined above, including migration, transnationality, cross-border crime, mobile criminal gangs, religious deviance, criminal sects and political crimes (such as revolt and assassination attempts) ${ }^{17}$.

The analyses should also take into account that dissenting actors and groups could likewise make use of such media as a component of their cultural and legal agency, and that popular media created cultural images and narratives of crime that could substantially diverge from the ones the criminal justice system generated or used. These ambiguous images of crime and criminal justice related to cultural diversity and deviance not only influenced general attitudes and fears, but can be studied as a key element of security and the associated discourses. During the early modern period, security developed into a leading category and main field of state activity (in particular in the areas of policing and criminal justice); however, as a fundamentally discursive construct, it was also related to threats, images, narratives and crimes based on cultural diversity and deviance, e.g. foreign intruders, mobile marginal groups, religious and political dissenters, sects and conspiracies.

Thus, a final perspective on the future of research could be to analyse how the specific interdependencies between cultural diversity and deviance (including the respective images and narratives thereof), the practices and modes of the criminal justice system in dealing with the related crimes as well as its interplay with public media and security discourses influenced the policing of politics and the emergence of transnational security regimes in Europe since the end of the early modern period ${ }^{18}$. It seems that the cultural dimension of early modern criminal justice, as outlined above, constitutes a promising approach to more closely connect the history of crime and criminal justice with long-term developments and current questions concerning cultural diversity in a "global world" that still challenges law and society.

Prof. Dr. Karl Härter Max Planck Institut für europäische Rechtsgeschichte 60323 Frankfurt am Main, Germany haerter@rg.mpg.de

\footnotetext{
16 Kalifa (2005); Shoemaker (2009); Wiltenburg (2012); Ward (2014); Härter (forthcoming).

17 Härter et al. (2010); Salomé (2012); Turrel (2012); Härter (2014a); Härter (2014b); Härter (2016).

18 Härter (2013).
} 


\section{BIBLIOGRAPHY}

Devereaux, S. and Griffiths, P. (Eds.) (2004) Penal Practice and Culture, 1500-1900: Punishing the English, New York: Palgrave Macmillan.

Foblets, M.-C., Gaudreault-DesBiens, J.-F. and Renteln, A.D (Eds.) (2010) Cultural Diversity and the Law: State Responses from around the World, Brussels: Bruylant.

Garnot, B. (Ed.) (2013) Etre brigand du Moyen Âge à nos jours, Paris: Colin.

Gerstenmayer, C. (2013) Spitzbuben und Erzbösewichter. Räuberbanden in Sachsen zwischen Strafverfolgung und medialer Repräsentation. Konstanz: UVK.

Härter, K. (2013) Security and Cross-border Political Crime: The Formation of Transnational Security Regimes in 18th and 19th Century Europe, Special Issue: Security and Conspiracy in History, 16th to 21st Century, Zwierlein, C., de Graaf, B. (Eds.), Historical Social Research, 38, p.96-106.

Härter, K. (2014a) Political Crime in early modern Europe: Assassination, Legal Responses and popular Print Media, European Journal of Criminology, 11, p.142-168.

Härter, K. (2014b) Early Modern Revolts as Political Crimes in the Popular Media of Illustrated Broadsheets, in Griesse, M. (Ed.), From Mutual Observation to Propaganda War. Premodern Revolts in Their Transnational Representations, Bielefeld: transcript.

Härter, K. (2016) Images of Dishonoured Rebels and Infamous Revolts: Political Crime, Shaming Punishments and Defamation in the Early Modern Pictorial Media, in Behrmann, C. (Ed.) Images of Shame. Infamy, Defamation and the Ethics of Oeconomia, Berlin/ Boston: De Gruyter.

Härter, K. (2017) Cultural Diversity, Deviance, Public Law and Criminal Justice in the Holy Roman Empire of the German Nation, in Ertl, T. and Kruijtzer, G. (Eds.), Law Addressing Diversity. Pre-Modern Europe and India in Comparison (12 th $18^{\text {th }}$ Centuries), Berlin/ Boston: De Gruyter Oldenbourg, p.56-94.

Härter, K., (forthcoming) The Culture of Early Modern Criminal Procedure: Communication, Print Media and Criminal Justice, in Rousseau, X., (Ed.), A Global History of Crime and Punishment, 4: A Global History of Crime and Punishment in the Enlightenment.

Härter, K. and De Benedictis, A. (Eds.) (2013) Revolten und politische Verbrechen zwischen dem 12. und 19. Jahrhundert. Rechtliche Reaktionen und juristisch-politische Diskurse/ Revolts and Political Crime from the $12^{\text {th }}$ to the $19^{\text {th }}$ Century. Legal Responses and JuridicalPolitical Discourses, Frankfurt am Main: Klostermann.

Härter, K. and de Graaf, B. (Eds.) (2012) Vom Majestätsverbrechen zum Terrorismus: Politische Kriminalität, Recht, Justiz und Polizei zwischen Früher Neuzeit und 20. Jahrhundert, Frankfurt am Main: Klostermann.

Härter, K., Sälter, G. and Wiebel, E. (Eds.) (2010) Repräsentationen von Kriminalität und öffentlicher Sicherheit. Bilder, Vorstellungen und Diskurse vom 16. bis zum 20. Jahrhundert (Studien zu Policey und Policeywissenschaft), Frankfurt am Main: Klostermann.

Kalifa, D. (2005) Crime et Culture au XIX $X^{e}$ Siècle, Paris: Perrin.

Kallenberg, V. (2015) Extrem alltäglich - Jüdinnen und Juden in der Frankfurter Strafgerichtsbarkeit (1780-1814), Darmstadt, Diss. phil. Technische Universität.

Kästner, A. and Schwerhoff, G. (Eds.) (2013) Göttlicher Zorn und menschliches Maß. Religiöse Devianz in frühneuzeitlichen Stadtgemeinschaften, Konstanz: UVK-Verlag-Gesellschaft. 
Knepper, P. (2010) The Invention of International Crime. A Global Issue in the Making, 18811914, London: Palgrave Macmillan.

Knepper, P. and Johansen, A. (Eds.) (2016) The Oxford Handbook of the History of Crime and Criminal Justice, Oxford: Oxford University Press.

Kymlicka, W., Lernestedt, C. and Matravers, M. (Eds.) (2014) Criminal Law and Cultural Diversity, Oxford: Oxford University Press.

Lemmings, D. and Walker, C. (Eds.) (2009) Moral Panics, the Media and the Law in early modern England, New York: Palgrave Macmillan.

Lévy, R. and Srebnick, A.G. (Eds.) (2005) Crime and Culture. An Historical Perspective, Burlington: Ashgate.

McMahon, R. (Ed.) (2008) Crime, Law and Popular Culture in Europe, 1500-1900, Cullompton: Willan.

Melossi, D., Sozzo, M. and Sparks, R. (Eds.) (2011) Travels of the Criminal Question. Cultural Embeddedness and Diffusion, Oxford: Hart.

Mersmann, B. and Kippenberg, H.G. (Eds.) (2016) The Humanities between Global Integration and Cultural Diversity, Berlin: De Gruyter.

Piltz, E. and Schwerhoff, G. (Eds.) (2015) Gottlosigkeit und Eigensinn. Religiöse Devianz im konfessionellen Zeitalter, Berlin: Duncker \& Humbolt.

Rousseaux, X. (2005) Rebels or Bandits? The Representations of the "Peasants' War" in Belgian Departments under French Rule (1798), in Lévy, R. and Srebnick, A.G. (Eds.) Crime and Culture: an Historical Perspective, Burlington: Ashgate.

Salomé, K. (2010) L'Ouragan homicide. L'attentat politique en France au XIX'e Siècle, Seyssel: Champ Vallon.

Salomé, K. (2012) Les représentations iconographiques de l'attentat politique au XIX ${ }^{\mathrm{e}}$ siècle, La Révolution Française, 2012, 1, [Online] http:///rf.revues.org/402

Shoemaker, R.B. (2009) Print Culture and the Creation of Public Knowledge about Crime in eighteenth-century London, in Knepper, P., Doak, J. and Shapland, J. (Eds.), Urban Crime Prevention, Surveillance, and Restorative Justice, London: CRC Press.

Turrel, D. (2012) Les usages iconographiques de l'assassinat d'Henri IV au XIX siècle, La Révolution Française, 2012, 1, [Online] http://lrf.revues.org/408

Ward, R.M. (2014) Print Culture, Crime and Justice in 18th-century London, London: Bloomsbury.

Wiltenburg, J. (2012) Crime and Culture in early modern Germany, Charlottesville, NC: Univ. of Virginia Press. 